\title{
SEGMENT PERFORMANCE REPORT SEBAGAI ALAT PENILAIAN PRESTASI MANAJER PADA PT. JANUR KAWANUA INDONESIA
}

\author{
Eric Ricardo Go \\ Grace Mogi \\ Rudy Pusung \\ Fakultas Ekonomi dan Bisnis Jurusan Akuntansi \\ Universitas Sam Ratulangi \\ email : eric_ricardogo@yahoo.com
}

\begin{abstract}
ABSTRAK
Setiap perusahaan memiliki pembagian tanggung jawab dan wewenang menurut bagiannya masingmasing. Untuk mengetahui sejauh mana kinerja setiap manajer setiap divisi menurut tugas dan tanggung jawab, maka perlu dilakukan penilaian prestasi manajer setiap divisi. Salah satu metode penilaian prestasi yaitu segment performance report. Peran seorang manajer sangat penting dalam mengendalikan berjalannya sebuah perusahaan. Dengan menggunakan segment performance report, laporan memuat pengelompokkan biaya-biaya tetap terkendali dan biaya tetap tidak terkendali. Tujuan penelitian ini adalah untuk mengetahui penggunaan segment performance report dalam menilai prestasi manajer. Penelitian ini dilakukan di PT. Janur Kawanua Indonesia beralamat di Manembo-nembo Bitung. Dalam penelitian ini, metode deskriptif (kualitatif) digunakan untuk membandingkan laporan rugi laba aktual serta laporan produksi yang telah dibuat oleh PT. Janur Kawanua Indonesia, sesuai dengan konsep segment performance report. Hasil penelitian ini menunjukkan perusahaan masih menggunakan laporan yang bersifat konvensional, laporan biaya produksi dan biaya operasional yang dihasilkan ini belum memisahkan antara biaya-biaya yang dapat dikendalikan dan biaya-biaya yang tak dapat dikendalikan. Dengan ini, dapat dilihat perbedaan setelah dipisahkan biaya tetap terkendali dan biaya tak terkendali pada divisi Tepung Kelapa sebesar Rp. 417.499.394,15. Dan pada divisi Kopra juga dapat dilihat perbedaan setelah dipisahkan antara biaya tetap terkendali dan biaya tidak terkendali sebesar Rp.127.081.716,91.
\end{abstract}

Kata kunci $\quad$ : segment performance report, penilaian prestasi manajer.

Each company has responsibility and authority sharing according to every part. For knowing how far the performance of a manager from every division according to the job and responsibility, achievement evaluation of every division is needed to be made. One method of achievement evaluation is segment performance report. The role of a manager is very important in controlling a company's operation. By using Segment Performance Report, report lists the classification the controllable fixed costs and uncontrollable fixed costs. This research's objective is to figure out the usage of segment performance report in evaluating manager achievement. This research is conducted in PT. Janur Kawanua Indonesia, addressed at Manembo-nembo Bitung. In this research,descriptive method (qualitative) is used for comparing the actual profit loss report and also production report that have been made by PT. Janur Kawanua Indonesia, based on the concept segment performance report. This research's result shows the company still uses this resulted conventional-based report, production cost report and operational costs have not separated among uncontrollable costs and uncontrollable costs. With this, it can be seen the difference after controllable fixed cost and controllable costs are separated at Tepung Kelapa, as much as 417,499,394.15 IDR. And at the Kopra Division, it can be also seen the difference after controllable fixed costs and uncontrollable costs are separated, as much as 127,081,716.91 IDR.

Keywords $\quad$ : segment performance report, manager achivement evalution. 


\section{Latar Belakang}

\section{PENDAHULUAN}

Pada saat ini Indonesia mulai terbuka atas perdagangan dunia, sehingga banyak terjalin kerjasama antar Indonesia dengan negara lain, misalnya dengan China dan Jepang. Hal ini memicu kekreatifan dan jiwa entrepreneur anak bangsa untuk membuat usaha sendiri, sehingga banyak munculnya home industry, perusahaan kecil, menengah, maupun sampai sebuah perusahaan beromset besar. Yang tentunya tiap perusahaan tidak hanya berfokus mencari keuntungan, tapi juga menciptakan produk atau jasa dengan mutu dan kualitas yang baik. Dalam mencapai sebuah visi dan misi atau tujuan yang diinginkan perusahaan, perusahaan harus memiliki manajemen perusahaan yang baik. Berhasil atau tidaknya sebuah perusahaan tergantung manajamen dalam menjalankan fungsinya. Koordinasi antara manajemen puncak dengan manajemen tiap lini yang baik dalam pembagian tugas maupun untuk memperoleh informasi. Perusahaan akan menetapkan sasaran yang ingin dicapai baik dalam jangka pendek maupun jangka panjang. Dalam hal ini dibuat oleh manajemen puncak dan untuk melaksanakannya didelegasikan ke manajer-manajer lini. Sehingga manajer memiliki tugas dan tanggung jawab yang harus dilakukan dengan target waktu yang telah ditentukan oleh manajemen puncak.

Kinerja merupakan suatu tolak ukur dalam sebuah perusahaan maupun individu dalam mencapai target yang telah ditentukan. Sehingga sering perusahaan menjadikan kinerja sebagai sebuah nilai dalam menentukan berhasil atau tidaknya perusahaan menjalankan perencanaan yang telah disusun. Dalam mengukur kinerja suatu perusahaan tidak terlepas dari kinerja seorang manajer. Peran seorang manajer sangat penting dalam mengendalikan berjalannya sebuah perusahaan. Seorang manajer membutuhkan informasi yang berguna untuk membantu dalam pengambilan keputusan. Manajer harus cermat dan tangkas dalam pengambilan keputusankeputusan taktis dalam menjalankan tugasnya, agar setiap tugas dapat dilakukan secara efektif dan efisien.

Untuk mengukur sejauh mana tugas dan tanggung jawab berjalan sesuai rencana, maka manajemen puncak melakukan penilaian atas kinerja manajer. Setiap tugas telah dilakukan dengan tepat atau apakah peran sudah berjalan dengan baik atau belum. Manajer memerlukan laporan atau informasi yang ditujukan kepada manajemen puncak berupa laporan pertanggung jawaban, serta laporan yang berkaitan dengan perusahaan untuk membantu dalam melaksanakan perencanaan dan pengambilan keputusan bagi perusahaan. Informasi yang dapat diperoleh yaitu segment performance report, ini merupakan laporan yang berisikan tentang pemisahan biaya-biaya yang dapat dikendalikan dan biaya-biaya yang tidak dapat dikendalikan oleh seseorang di dalam posisi organisasinya, sehingga menggambarkan prestasi sebenarnya.

\section{Tujuan Penelitian}

Berdasarkan perumusan masalah yang terjadi, maka tujuan penelitian adalah untuk mengetahu dan menganalisa penggunaan segment performance report dalam menilai prestasi manajer pada PT. Janur Kawanua Indonesia.

\section{Akuntansi Manajemen}

\section{TINJAUAN PUSTAKA}

Simamora (2012:13), mendefinisikan akuntansi manajemen adalah proses pengidentifikasian, pengukuran, penghimpunan, penganalisisan, penyusunan, penafsiran, dan pengkomunikasian informasi keuangan yang digunakan manajemen untuk merencanakan, mengevaluasi, dan mengendalikan kegiatan usaha di dalam sebuah organisasi, serta untuk memastikan penggunaan dan akuntabilitas sumber daya yang tepat. Identifikasi melibatkan pengakuan dan evaluasi peristiwa-peristiwa ekonomik dan transaksi bisnis untuk tindakan akuntansi yang tepat.

Samryn (2012:4) mendefinisikan akuntansi manajemen merupakan bidang akuntansi yang berfokus pada penyediaan, termasuk pengembangan dan penafsiran informasi akuntansi bagi para manajer untuk digunakan sebagai bahan perencanaan, pengendalian operasi dan dalam pengambilan keputusan. Sesuai dengan fungsi tersebut, maka akuntansi manajemen dapat digunakan sebagai pendukung pelaksanaan fungsi-fungsi manajemen dalam bidang riset dan pengembangan, produksi, pemasaran, distribusi dan logistik, serta pelayanan pelanggan.

\section{Fungsi Informasi Akuntansi}


Anthony dan Dearden (2003:152), informasi sebagai fungsi evaluasi, yaitu mengungkapkan sampai sejauh mana tindakan yang telah direncanakan dan pencapaian hasil yang diharapkan.

\section{Sistem Pengendalian Manajemen}

Halim, dkk (2009:13), mendefinisikan sistem pengendalian manajemen adalah sebagai suatu alat dari alat-alat lainnya untuk mengimplementasikan strategi, yang berfungsi untuk memotivasi anggota-anggota organisasi guna mencapai tujuan organisasi.

\section{Akuntansi Pertanggungjawaban}

Samryn (2012:261), mendefinisikan akuntansi pertanggunjawaban merupakan suatu sistem akuntansi yang digunakan untuk mengukur kinerja setiap pusat pertanggungjawaban sesuai informasi yang dibutuhkan manajer untuk mengoperasikan pusat pertanggungjawaban mereka sebagai bagian dari sistem pengendalian manajemen.

Warindrani (2006:122), mendefinisikan akuntansi pertanggung jawaban merupakan suatu sistem yang mengukur hasil-hasil dari suatu pusat pertanggungjawaban memainkan peranan penting dalam mengukur kegiatan dan hasil suatu pusat pertanggungjawaban.

\section{Biaya Tetap Terkendali}

Simamora (2012:54), mendefinisikan biaya tetap terkendali (controllable cost) adalah biaya dalam sebuah pusat pertanggungjawaban yang dapat dipengaruhi secara signifikan oleh seorang manajer pusat pertanggungjawaban selama rentang waktu tertentu.

\section{Biaya Tidak Terkendali}

Simamora (2012:54), mendefinisikan biaya tidak terkendali (uncontrollable cost) adalah setiap biaya yang tidak dapat dipengaruhi oleh seorang manajer sebuah pusat pertanggungjawaban dalam rentang waktu tertentu.

\section{Penilaian Prestasi}

Mulyadi (2006:116-117), mendefinisikan pengukuran kinerja merupakan alat manajemen untuk menilai keberhasilan maupun kegagalan pelaksanaan strategik untuk mencapai tujuan dan sasaran orang yang bersangkutan. Kinerja atau nilai aktivitas kerja dapat diartikan sebagai prestasi. Prestasi yang dimaksud adalah efektivitas operasional perusahaan, baik secara keseluruhan maupun personal seorang manajer dalam mewujudkan sasaran, tujuan, visi perusahaan.

\section{Segment Performance Report}

Nizar dan Syahrul (2000:758), Segment performance report adalah laporan yang berisikan pemisahan antara biaya-biaya yang dapat dikendalikan dan biaya-biaya yang tidak dapat dikendalikan oleh seseorang dalam posisi organisasinya, sehingga menggambarkan prestasi yang sebenarnya.

\section{Konsep Segment Performance Report}

\section{Tabel 1 Konsep Segment Performance Report}

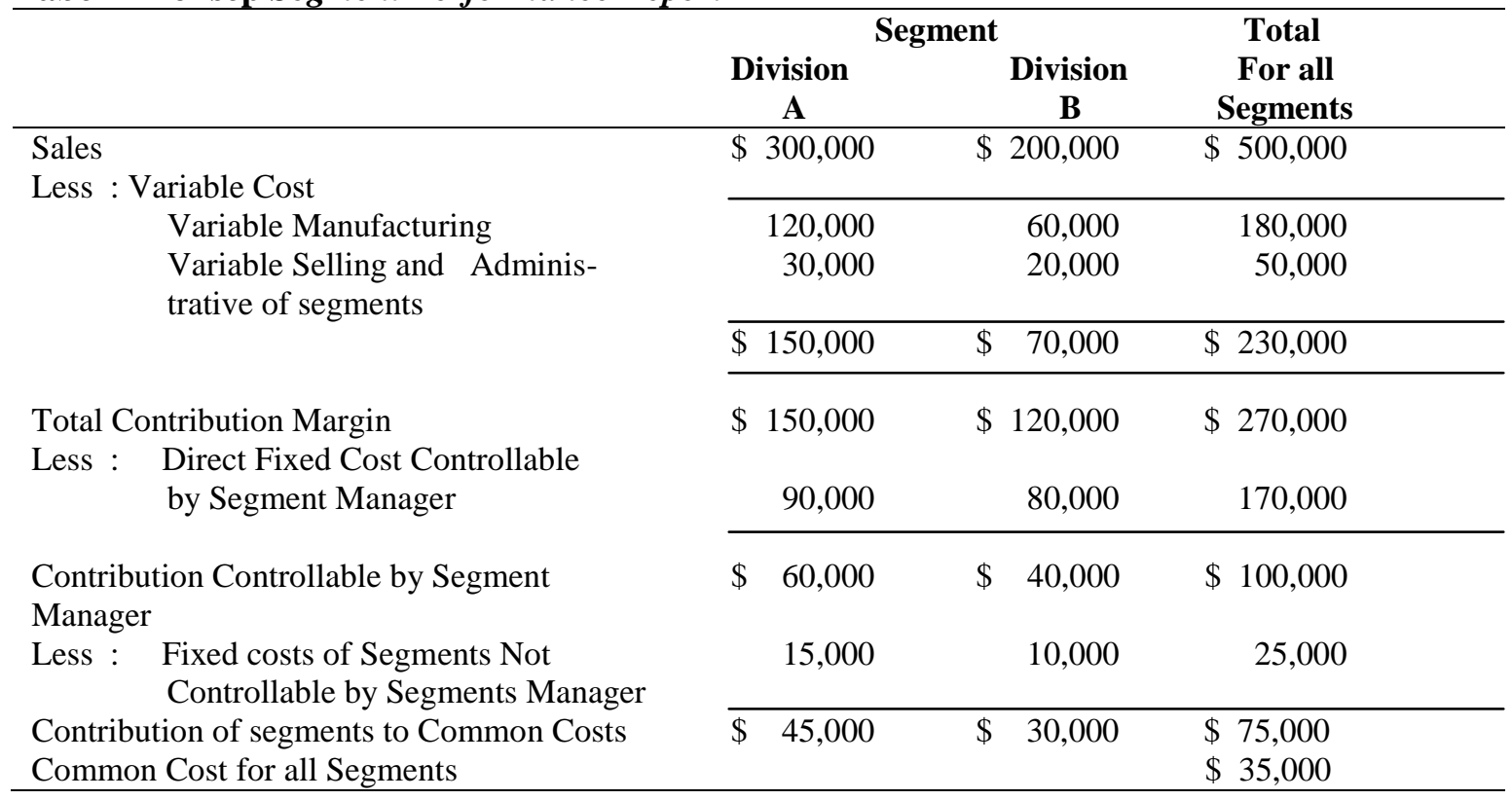


Net Income $\$ 40,000$

Sumber: Barbee, Fred: Princeples Of Accounting (2013)

1. Total contribution margin

adalah jumlah yang dikontribusikan untuk menutup biaya tetapnya. Total contribution margin ini di dapat dari penjualan dikurangi dengan biaya variabel. Dan biaya terkendali ini merupakan biaya bagi manajer pusat laba tersebut.

2. Contribution controllable by segment manager

Adalah biaya-biaya tetap yang dapat dikendalikan oleh manajer dengan pusat laba, termasuk didalamnya commited fixed cost dan discretionary fixed cost.

3. Contribution of segment to common cost

Merupakan sisa yang akan dialokasikan untuk common cost. Common cost ini tidak dapat dikendalikan oleh manajer pusat laba.

Jadi, untuk menilai prestasi manajer pusat laba yaitu dengan memakai segment income statement dengan bagian yang dinilai adalah contribution controllable by segment manager.

Penelitian Terdahulu.

Tabel 2 Penelitian Terdahulu

\begin{tabular}{|c|c|c|c|c|c|c|}
\hline $\begin{array}{c}\text { Nama } \\
\text { Peneliti / } \\
\text { Tahun } \\
\end{array}$ & Judul & Tujuan & $\begin{array}{c}\text { Metode } \\
\text { Penelitian }\end{array}$ & Hasil Penelitian & Imaan & daan \\
\hline $\begin{array}{l}\text { Sanger } \\
(2005)\end{array}$ & $\begin{array}{l}\text { Penerapan } \\
\text { Segment } \\
\text { Performance } \\
\text { Report Sebagai } \\
\text { Alat Penilaian } \\
\text { Prestasi Manajer } \\
\text { Divisi Pada PT. } \\
\text { Astra } \\
\text { International } \\
\text { Isuzu Manado }\end{array}$ & $\begin{array}{l}\text { Untuk } \\
\text { mengetahui } \\
\text { Penerapan } \\
\text { Segment } \\
\text { Performance } \\
\text { Report Sebagai } \\
\text { Alat Penilaian } \\
\text { Prestasi Manajer } \\
\text { Divisi Pada PT. } \\
\text { Astra } \\
\text { International } \\
\text { Isuzu Manado }\end{array}$ & $\begin{array}{l}\text { Metode } \\
\text { Deskriptif }\end{array}$ & $\begin{array}{l}\text { Perusahaan } \\
\text { masih } \\
\text { menggunakan } \\
\text { laporan yang } \\
\text { bersifat } \\
\text { konvensional, } \\
\text { tanpa melihat } \\
\text { kontribusi dari } \\
\text { divisi }\end{array}$ & $\begin{array}{l}\text { Penelitian ini } \\
\text { memiliki } \\
\text { kesamaan } \\
\text { menggunakan } \\
\text { Segment } \\
\text { Performance } \\
\text { Report untuk } \\
\text { menilai } \\
\text { prestasi } \\
\text { manajer }\end{array}$ & $\begin{array}{l}\text { Tetapi } \\
\text { perbedaan } \\
\text { penelitian } \\
\text { ini pada } \\
\text { objek } \\
\text { penelitian } \\
\text { yang } \\
\text { berbeda }\end{array}$ \\
\hline $\begin{array}{l}\text { Uli } \\
\text { (2009) }\end{array}$ & $\begin{array}{l}\text { Analisis } \\
\text { Penerapan } \\
\text { Akuntansi } \\
\text { Pertanggung } \\
\text { Jawaban Sebagai } \\
\text { Alat Penilaian } \\
\text { Kinerja Manajer } \\
\text { Pusat Pendapatan } \\
\text { Pada PT. Astra } \\
\text { International } \\
\text { cabang } \\
\text { Sisingamangaraja }\end{array}$ & $\begin{array}{l}\text { Tujuannya } \\
\text { apakah manajer } \\
\text { pusat pendapatan } \\
\text { sesuai dengan } \\
\text { tanggung jawab } \\
\text { sebagai manajer }\end{array}$ & $\begin{array}{l}\text { Metode } \\
\text { Deskriptif }\end{array}$ & $\begin{array}{l}\text { Penerapan } \\
\text { akuntansi } \\
\text { pertanggung } \\
\text { jawaban sangat } \\
\text { efektif untuk } \\
\text { menilai kinerja } \\
\text { manajer pusat } \\
\text { pendapatan dan } \\
\text { hasil dari kinerja } \\
\text { manajer sangat } \\
\text { sesuai dengan } \\
\text { tujuan pimpinan }\end{array}$ & $\begin{array}{l}\text { Penilaian ini } \\
\text { hampir sama } \\
\text { dengan } \\
\text { penulis dalam } \\
\text { menilai } \\
\text { kinerja } \\
\text { manajer }\end{array}$ & $\begin{array}{l}\text { Yang } \\
\text { membedakan } \\
\text { penelitian ini } \\
\text { adalah } \\
\text { penulis } \\
\text { membahas } \\
\text { dengan } \\
\text { Segment } \\
\text { Performance } \\
\text { Report untuk } \\
\text { mengukur } \\
\text { kinerja } \\
\text { manajer }\end{array}$ \\
\hline
\end{tabular}

\section{Jenis Penelitian}

\section{METODE PENELITIAN}

penelitian ini dengan metode deskriptif (kualitatif), membandingkan laporan rugi laba aktual serta laporan produksi yang telah dibuat oleh perusahaan sesuai dengan konsep Segment Performance Report.

\section{Jenis dan Sumber Data}

Data adalah sekumpulan informasi yang diperlukan untuk pengambilan keputusan. Data merupakan keterangan-keterangan yang diperoleh dari suatu penelitian yang dapat digunakan untuk menganalisa 
permasalahan yang dihadapi dan selanjutnya untuk mencari alternatif yang sesuai. Data dapat diklasifikasikan menjadi dua jenis yaitu data kuantitatif dan data kualitatif.

Data yang dibutuhkan dalam penelitian ini adalah data kualitatif dan data kuantitatif yaitu struktur organisasi, job description, laporan biaya produksi dan laporan laba rugi PT. Janur Kawanua Indonesia.

\section{Metode Analisis Data}

Analisis Deskriptif adalah untuk memuat penggambaran secara sistematis, faktual, dan akurat mengenai fakta-fakta dan sifat-sifat objek penelitian serta memeriksa sebab-sebab dari suatu gejala tertentu. Atau penelitian yang bermaksud untuk memuat deskripsi mengenai situasi-situasi atau kejadian-kejadian. Analisis deskriptif (kualitatif) berusaha mengubah kumpulan data mentah menjadi bentuk atau gambaran yang mudah dipahami dalam informasi yang lebih ringkas.

Dalam penelitian ini dengan metode deskriptif (kualitatif), membandingkan laporan rugi laba aktual serta laporan produksi yang telah dibuat oleh perusahaan sesuai dengan konsep Segment Performance Report.

\section{Hasil Penelitian}

\section{HASIL PENELITIAN DAN PEMBAHASAN}

Dari hasil penelitian yang di dapat dari perusahaan, berikut disertakan laporan-laporan biaya produksi maupun laporan rugi laba perusahaan.

Tabel 3 PT. Janur Kawanua Indonesia Laporan Biaya Produksi Periode 1 Januari 2012 - 31 Desember 2012

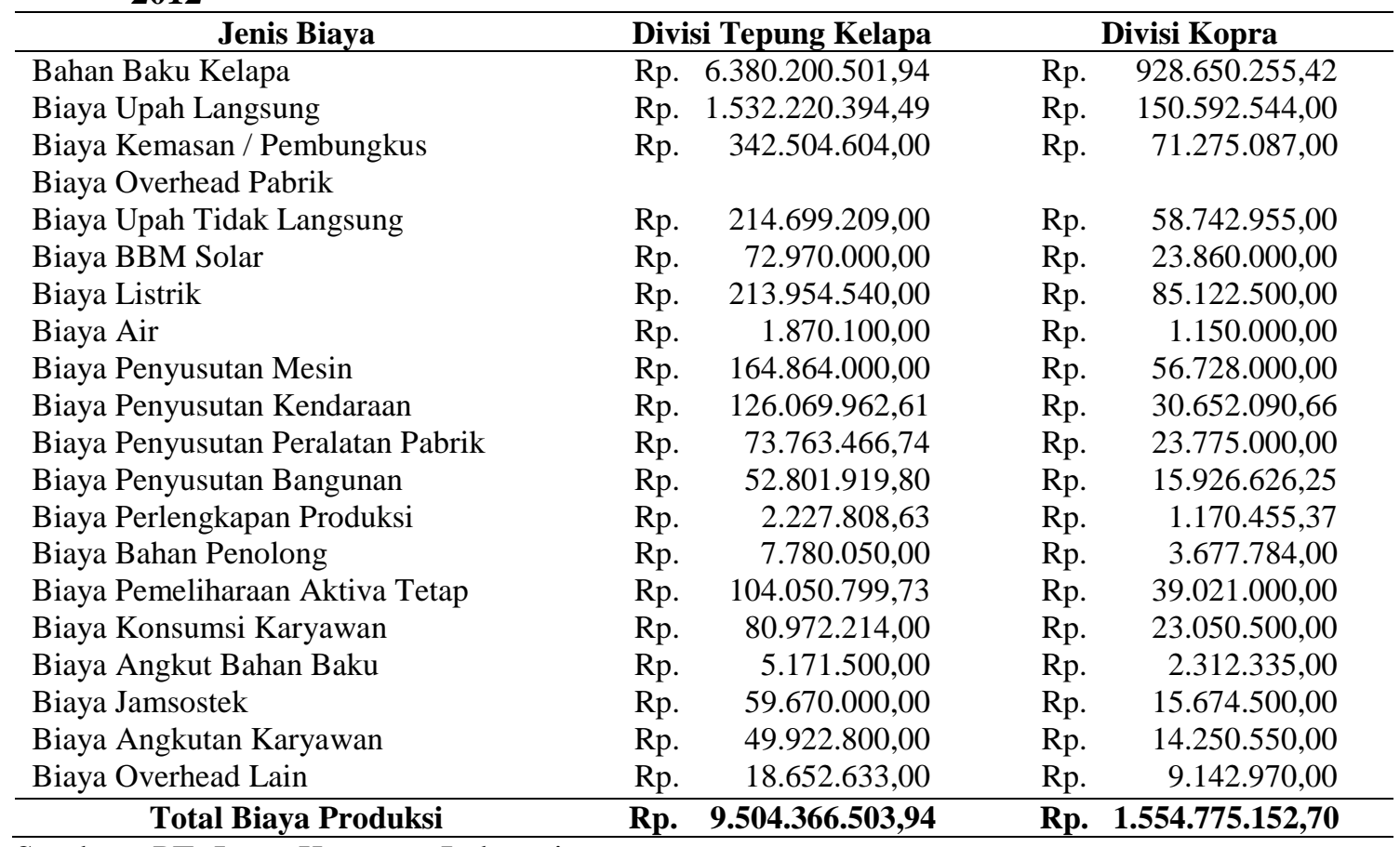

Sumber : PT. Janur Kawanua Indonesia 
Tabel 4 PT. Janur Kawanua Indonesia Laporan Rugi Laba periode 1 Januari 2012 - 31 Desember 2012 Jumlah

\begin{tabular}{|c|c|}
\hline Penjualan: & \\
\hline Penjualan Export - Tepung Kelapa & Rp. 11.100.128.656,25 \\
\hline Penjualan Lokal - Kopra & $1.810 .803 .309,00$ \\
\hline Total Penjualan & Rp. 12.910.931.964,25 \\
\hline Harga Pokok Penjualan: & \\
\hline Divisi Tepung Kelapa & \\
\hline Total Biaya Produksi & Rp. 9.504.366.503,94 \\
\hline Persediaan Barang Jadi Awal & $4.672 .142 .008,09$ \\
\hline Jumlah Barang Jadi Tersedia Dijual & $\overline{\text { Rp. } 14.176 .508 .512,03}$ \\
\hline Persediaan Barang Jadi Akhir & $(\quad 4.733 .529 .940,31)$ \\
\hline HPP Tepung Kelapa & Rp. $9.442 .978 .571,72$ \\
\hline Divisi Kopra & \\
\hline Total Biaya Produksi & Rp. $1.554 .775 .152,70$ \\
\hline Persediaan Barang Jadi Awal & $288.160 .260,00$ \\
\hline Jumlah Barang Jadi Tersedia Dijual & Rp. $1.842 .935 .412,70$ \\
\hline Persediaan Barang Jadi Akhir & $(\quad 552.082 .618,87)$ \\
\hline HPP Kelapa Kopra & Rp. $1.288 .852 .793,83$ \\
\hline Harga Pokok Penjualan & Rp. 10.731.831.365,55 \\
\hline Laba Kotor & Rp. $2.179 .100 .598,69$ \\
\hline Biaya Operasional & $\begin{array}{l}1.990 .204 .496,50 \\
\end{array}$ \\
\hline Laba Bersih Operasional & Rp. $\quad 188.896 .102,19$ \\
\hline Pendapatan Luar Usaha: & \\
\hline Pendapatan Jasa Giro & $6.667 .959,55$ \\
\hline Pendapatan Lain-Lain & $24.534 .221,00$ \\
\hline Total Pendapatan Luar Usaha & $31.202 .180,55$ \\
\hline Laba Sebelum Pajak & Rp. $\quad 220.098 .282,74$ \\
\hline
\end{tabular}

Sumber: PT. Janur Kawanua Indonesia

Penelitian ini dilakukan pada PT. Janur Kawanua, dilihat dari pembahasan di atas bahwa laporan yang dihasilkan oleh bagian produksi sebagai saran pertanggung jawaban dan pengukuran prestasi belum memadai. Belum adanya pemisahan biaya membuat laporan sebagai penilaian prestasi belum terlalu akurat, juga karena manajer produksi maupun pimpinan pusat belum menyadari sepenuhnya arti penting dari laporan untuk tujuan pengendalian, yang dalam hal ini Segment Performance Report. Sebagai contoh pimpinan pusat dalam menilai prestasi manajer produksi berdasarkan laba rugi yang diperoleh dalam suatu periode tertentu. Selain itu, staf dari manajer produksi belum sepenuhnya memahami esensi dari laporan yang digunakan sebagai sarana penilaian atau pengukuran prestasi. Contohnya, belum diklasifikasikannya biaya variabel, biaya tetap terkendali dan biaya tak terkendali. Tidak memadainya laporan prestasi ini tanpa disadari oleh manajer produksi hal ini membawa dampak bagi manajer produksi, khususnya menyangkut motivasi kerja.

Keadaan ini digambarkan dengan kenyataan yang ada, bahwa manajer produksi setiap divisi, Tepung Kelapa dan Kopra, merasa prestasinya diukur dengan membebankan semua biaya baik dari pusat atau pun dari bagiannya. Laporan setiap divisi yang dibuat belum memisahkan antara biaya variabel, biaya tetap terkendali dan biaya tak terkendali. Supaya hal tersebut bisa diatasi maka laporan tersebut perlu diadakan penyesuaian dengan Segment Performance Report. Penyesuaian yang dilakukan harus menentukan atau memisahkan setiap biaya berdasarkan sifatnya, biaya tetap terkendali dan biaya tak terkendali. Penyesuaian yang dilakukan dapat dilihat dalam tabel berikut. 
Tabel 5 PT. Janur Kawanua Indonesia Laporan Biaya Produksi Divisi Tepung Kelapa Periode 1 Januari 2012 - 31 Desember 2012

\begin{tabular}{|c|c|c|c|}
\hline Jenis Biaya & Rill & $\begin{array}{c}\text { S.P.R } \\
\text { (Biaya Terkendali) } \\
\end{array}$ & $\begin{array}{c}\text { Selisih } \\
\text { (Biaya Tak Terkendali) }\end{array}$ \\
\hline Bahan Baku Kelapa & Rp. 6.380.200.501,94 & Rp. 6.380.200.501,94 & \\
\hline Biaya Upah Langsung & Rp. $1.532 .220 .394,49$ & Rp. 1.532.220.394,49 & \\
\hline Biaya Kemasan / Pembungkus & $342.504 .604,00$ & $342.504 .604,00$ & \\
\hline Biaya Overhead Pabrik & & & \\
\hline Biaya Upah Tidak Langsung & 214.699.209,00 & 214.699.209,00 & \\
\hline Biaya BBM Solar & $72.970 .000,00$ & $72.970 .000,00$ & \\
\hline Biaya Listrik & 213.954.540,00 & 213.954.540,00 & \\
\hline Biaya Air & $1.870 .100,00$ & $1.870 .100,00$ & \\
\hline Biaya Penyusutan Mesin & $164.864 .000,00$ & - & Rp. $164.864 .000,00$ \\
\hline Biaya Penyusutan Kendaraan & 126.069.962,61 & - & Rp. $126.069 .962,61$ \\
\hline Biaya Penyusutan Peralatan & $73.763 .466,74$ & - & $73.763 .466,74$ \\
\hline Pabrik & $52.801 .919,80$ & - & $52.801 .919,80$ \\
\hline Biaya Penyusutan Bangunan & $2.227 .808,63$ & $2.227 .808,63$ & \\
\hline Biaya Perlengkapan Produksi & $7.780 .050,00$ & $7.780 .050,00$ & \\
\hline Biaya Bahan Penolong & $104.050 .799,73$ & 104.050.799,73 & \\
\hline Biaya Pemeliharaan Aktiva Tetap & $80.972 .214,00$ & $80.972 .214,00$ & \\
\hline Biaya Konsumsi Karyawan & $5.171 .500,00$ & $5.171 .500,00$ & \\
\hline Biaya Angkut Bahan Baku & $59.670 .000,00$ & $59.670 .000,00$ & \\
\hline Biaya Jamsostek & $49.922 .800,00$ & $49.922 .800,00$ & \\
\hline $\begin{array}{l}\text { Biaya Angkutan Karyawan } \\
\text { Biaya Overhead Lain }\end{array}$ & $18.652 .633,00$ & $18.652 .633,00$ & \\
\hline
\end{tabular}
Total Biaya Produksi
Rp. $9.504 .366 .503,94 \quad$ Rp. $9.086 .867 .109,79$
Rp. 417.499.394,15

Sumber : Hasil Olahan Penulis

Tabel 6 PT. Janur Kawanua Indonesia Laporan Biaya Produksi Divisi Kopra Periode 1 Januari 2012 31 Desember 2012

\begin{tabular}{|c|c|c|c|c|c|}
\hline \multirow{2}{*}{$\begin{array}{l}\text { Jenis Biaya } \\
\text { Bahan Baku Kelapa }\end{array}$} & \multicolumn{2}{|r|}{ Rill } & \multicolumn{2}{|c|}{$\begin{array}{c}\text { S.P.R } \\
\text { (Biaya Terkendali) }\end{array}$} & $\begin{array}{c}\text { Selisih } \\
\text { (Biaya Tak } \\
\text { Terkendali) } \\
\end{array}$ \\
\hline & Rp. & $928.650 .255,42$ & Rp. & $928.650 .255,42$ & \\
\hline Biaya Upah Langsung & $\mathrm{Rp}$. & $150.592 .544,00$ & $\mathrm{Rp}$. & $150.592 .544,00$ & \\
\hline Biaya Kemasan / Pembungkus & $\mathrm{Rp}$. & $71.275 .087,00$ & Rp. & $71.275 .087,00$ & \\
\hline Biaya Overhead Pabrik & & & & & \\
\hline Biaya Upah Tidak Langsung & Rp. & $58.742 .955,00$ & Rp. & $58.742 .955,00$ & \\
\hline Biaya BBM Solar & Rp. & $23.860 .000,00$ & Rp. & $23.860 .000,00$ & \\
\hline Biaya Listrik & $\mathrm{Rp}$. & $85.122 .500,00$ & $\mathrm{Rp}$. & $85.122 .500,00$ & \\
\hline Biaya Air & Rp. & $1.150 .000,00$ & Rp. & $1.150 .000,00$ & \\
\hline Biaya Penyusutan Mesin & $\mathrm{Rp}$. & $56.728 .000,00$ & & - & Rp $\quad 56.728 .000,00$ \\
\hline Biaya Penyusutan Kendaraan & Rp. & $30.652 .090,66$ & & - & $\operatorname{Rp} \quad 30.652 .090,66$ \\
\hline Biaya Penyusutan Peralatan Pabrik & $\mathrm{Rp}$. & $23.775 .000,00$ & & - & Rp. $23.775 .000,00$ \\
\hline Biaya Penyusutan Bangunan & $\mathrm{Rp}$. & $15.926 .626,25$ & & - & Rp. $15.926 .626,25$ \\
\hline Biaya Perlengkapan Produksi & Rp. & $1.170 .455,37$ & Rp. & $1.170 .455,37$ & \\
\hline Biaya Bahan Penolong & $\mathrm{Rp}$. & $3.677 .784,00$ & Rp. & $3.677 .784,00$ & \\
\hline Biaya Pemeliharaan Aktiva Tetap & Rp. & $39.021 .000,00$ & Rp. & $39.021 .000,00$ & \\
\hline Biaya Konsumsi Karyawan & $\mathrm{Rp}$. & $23.050 .500,00$ & $\mathrm{Rp}$. & $23.050 .500,00$ & \\
\hline Biaya Angkut Bahan Baku & $\mathrm{Rp}$. & $2.312 .335,00$ & $\mathrm{Rp}$. & $2.312 .335,00$ & \\
\hline Biaya Jamsostek & $\mathrm{Rp}$. & $15.674 .500,00$ & Rp. & $15.674 .500,00$ & \\
\hline Biaya Angkutan Karyawan & Rp. & $14.250 .550,00$ & $\mathrm{Rp}$. & $14.250 .550,00$ & \\
\hline Biaya Overhead Lain & $\mathrm{Rp}$. & $9.142 .970,00$ & Rp. & $9.142 .970,00$ & \\
\hline
\end{tabular}

Total Biaya Produksi

Rp. 1.554.775.152,70 Rp. 1.427.693.435,79

Rp. 127.081.716,91

Sumber : Hasil Olahan Penulis 
Setelah dipisahkan atau dikelompokkan biaya tetap yang dapat dikendalikan dan biaya yang tidak dapat dikendalikan dari seorang manajer produksi, dapat dilihat sampai mana biaya yang menjadi tanggung jawab dan wewenang dari seorang manajer produksi masing-masing divisi tersebut. Pada divisi Tepung Kelapa (Tabel 5) dapat kita lihat perbedaan setelah dipisahkan biaya tetap terkendali dan biaya tak terkendali sebesar Rp. 417.499.394,15. Dan pada divisi Kopra (Tabel 6) kita juga dapat melihat perbedaan setelah dipisahkan antara biaya tetap terkendali dan biaya tidak terkendali sebesar Rp.127.081.716,91. Selisih yang terjadi antara laporan rill yang dibuat perusahaan dengan Segment Performance Report merupakan biaya yang tidak dapat dikendalikan oleh manajer produksi menurut tanggung jawab dan wewenangnya, yaitu biaya penyusutan mesin, biaya penyusutan kendaraan, biaya penyusutan peralatan pabrik, biaya penyusutan bangunan. Biaya ini merupakan keputusan dari manajer puncak atau yang lebih tinggi posisinya yang tidak dapat diganggu gugat oleh manajer produksi. Sehingga jika biaya tak terkendali ini turut dimasukkan dalam laporan prestasi, laporan tersebut tidak memadai pengukuran prestasi manajer produksi yang sebenarnya. Namun setelah dipisahkan seperti Tabel 5 dan Tabel 6 direktur utama atau manajer puncak dapat melihat biaya-biaya yang benar-benar dapat dikendalikan manajer produksi menurut tanggung jawab dan wewenangnya.

Dalam laporan rugi laba (Tabel 4) yang dihasilkan perusahaan belum dikurangi oleh biaya-biaya yang tidak terkendali, sehingga belum memadai dalam laporan pertanggung jawaban atau laporan prestasi. Namun setelah dipisahkan setiap biaya variabel, biaya tetap terkendali dan biaya tak terkendali, dapat dilakukan penyesuaian atas laporan prestasi atau laporan pertanggung jawaban. Penyesuaian-penyesuaian terhadap laporan prestasi yang digunakan oleh divisi, dibutuhkan dalam suatu perusahaan dalam menjalankannnya. Karena penilaian atau pengukuran prestasi manajer didasarkan atas kontribusi dari divisi dengan hanya memperhitungkan biaya-biaya tetap yang dapat dikendalikan oleh manajer divisi yang bersangkutan. Secara tidak langsung hal ini memunculkan rasa percaya diri atau motivasi kerja seorang manajer. Penyesuaian yang dimaksud diatas dapat dilihat pada tabel.

Tabel 7 PT. Janur Kawanua Indonesia Laporan Harga Pokok Penjualan (Variabel) Periode 1 Januari 2012 - 31 Desember 2012

\begin{tabular}{|c|c|c|}
\hline & Divisi Tepung Kelapa & Divisi Kopra \\
\hline \multicolumn{3}{|l|}{ Biaya Variabel: } \\
\hline Bahan Baku Kelapa & Rp. $\quad 6.380 .200 .501,94$ & $928.650 .255,42$ \\
\hline Biaya Upah Langsung & $1.532 .220 .394,49$ & $150.592 .544,00$ \\
\hline Biaya Kemasan / Pembungkus & $342.504 .604,00$ & $71.275 .087,00$ \\
\hline Biaya BBM Solar & $72.970 .000,00$ & $23.860 .000,00$ \\
\hline Biaya Perlengkapan Produksi & $2.227 .808,63$ & $1.170 .455,37$ \\
\hline Biaya Bahan Penolong & $7.780 .050,00$ & $3.677 .784,00$ \\
\hline Harga Pokok Porduksi Variabel & Rp. 8.337.903.358,56 & Rp. $1.179 .226 .125,79$ \\
\hline \multirow[t]{2}{*}{ Persediaan Awal Variabel } & 2.813.822.203,39 & 197.753.359,00 \\
\hline & Rp. 11.151.725.561,95 & Rp. $1.376 .979 .484,79$ \\
\hline Persediaan Akhir Variabel & 3.044.935.717,31 & $426.413 .643,87$ \\
\hline Harga Pokok Penjualan Variabel & Rp. 8.106.789.844,64 & $950.565 .840,92$ \\
\hline
\end{tabular}

Sumber: Hasil Olahan Penulis 
Tabel 8 PT. Janur Kawanua Indonesia Segment Performance Report periode 1 Januari 2012 - 31 Desember 2012

\begin{tabular}{|c|c|c|c|}
\hline & Divisi Tepung Kelapa & Divisi Kopra & Total Divisi \\
\hline Penjualan & Rp. 11.100.128.656,25 & Rp. $1.810 .803 .309,00$ & Rp.12.910.931.965,25 \\
\hline Harga Pokok Penjualan Variabel & Rp. $\quad 8.106 .789 .844,64$ & Rp. $950.565 .840,92$ & \\
\hline Biaya Operasi Variabel & $321.818 .854,50$ & $104.958 .711,00$ & \\
\hline Total Biaya Variabel & Rp. $8.428 .608 .699,14$ & Rp. 1.055.524.551,92 & Rp. 9.484.133.251,06 \\
\hline Kontribusi Margin & Rp. $\quad 2.617 .519 .957,11$ & Rp. $\quad 755.278 .757 .08$ & Rp. 3.372.798.714,19 \\
\hline Biaya Tetap Terkendali: & & & \\
\hline Biaya Listrik & $213.954 .540,00$ & $85.122 .500,00$ & \\
\hline Biaya Air & $1.870 .100,00$ & $1.150 .000,00$ & \\
\hline Biaya Pemeliharaan Aktiva Tetap & $104.050 .799,73$ & $39.021 .000,00$ & \\
\hline Biaya Konsumsi Karyawan & $80.972 .214,00$ & $23.050 .500,00$ & \\
\hline Biaya Angkut Bahan Baku & $5.171 .500,00$ & $2.312 .335,00$ & \\
\hline Biaya Jamsostek & $59.670 .000,00$ & $15.674 .500,00$ & \\
\hline Biaya Angkutan Karyawan & $49.922 .800,00$ & $14.250 .550,00$ & \\
\hline Biaya Overhead Lain & $18.652 .633,00$ & $9.142 .970,00$ & \\
\hline Biaya Upah Tidak Langsung & $214.699 .209,00$ & $58.742 .955,00$ & \\
\hline \multirow[t]{2}{*}{ Biaya Operasi Tetap } & 568.590 .522 .00 & $210.339 .847,00$ & \\
\hline & $\begin{array}{ll}\text { Rp. } & 1.317 .554 .317,73 \\
\end{array}$ & $458.807 .157,00$ & $\underline{\text { Rp. 1.736.219.622,23 }}$ \\
\hline $\begin{array}{l}\text { Kontribusi Yang Dapat Dikontrol - } \\
\text { oleh Divisi }\end{array}$ & Rp. $1.299 .965 .639,38$ & 296.471.600,08 & Rp. 1.596.437.239,46 \\
\hline Biaya Tetap Tidak Terkendali: & & & \\
\hline Biaya Penyusutan Mesin & $164.864 .000,00$ & $56.728 .000,00$ & \\
\hline Biaya Penyusutan Kendaraan & $126.069 .962,61$ & $30.652 .090,66$ & \\
\hline Biaya Penyusutan Peralatan Pabrik & $73.763 .466,74$ & $23.775 .000,00$ & \\
\hline \multirow[t]{2}{*}{ Biaya Penyusutan Bangunan } & $52.801 .919,80$ & $15.926 .626,25$ & \\
\hline & $417.499 .349,15$ & $\begin{array}{ll}\text { Rp. } & 127.081 .716,91 \\
\end{array}$ & Rp. $\quad 544.581 .066,06$ \\
\hline Kontribusi Segment Kepada - & & & \\
\hline Common Costs & 882.466.290,23 & Rp. $\quad 163.389 .883,17$ & Rp. $1.045 .856 .173,40$ \\
\hline Common Costs: & & & \\
\hline Gaji Direktur Utama & & & $180.000 .000,00$ \\
\hline \multirow[t]{2}{*}{ Biaya Bunga Bank } & & & Rp. $\quad 676.960 .071,21$ \\
\hline & & & Rp. $\quad 856.960 .071,21$ \\
\hline Laba Bersih Operasional & & & Rp. $\quad 188.896 .102,19$ \\
\hline
\end{tabular}

Sumber: Hasil Olahan Penulis

Penjelasan Tabel 8 sebagai berikut:

1. Penjualan

Penjualan dalam pos ini merupakan seluruh hasil penjualan produksi yang diperoleh dari kegiatan penjualan dari perusahaan.

2. Biaya Variabel

Yang dimaksud dengan biaya variabel disini adalah biaya yang dikeluarkan oleh bagian sehubungan dengan kegiatan yang dilakukan oleh masing-masing divisi/bagian.

3. Kontribusi margin

Kontribusi margin yang dimaksud yaitu selisih antara pendapatan dengan biaya-biaya variabel yang dikeluarkan oleh masing-masing divisi/bagian.

4. Biaya tetap terkendali

Yang dimaksud dengan biaya tetap terkendali yaitu biaya-biaya yang dikeluarkan oleh manajer produksi yang sifatnya dapat dikendalikan oleh manajer divisi.

5. Kontribusi divisi

Kontribusi divisi merupakan sumbangan dari bagian yang bersangkutan pada bagian yang diperoleh melalui selisih antara penjualan dengan biaya-biaya tetap yang dapat dikendalikan oleh manajer divisi.

6. Biaya tak terkendali 
Yang dimaksud dengan biaya tak terkendali bagi bagian ini yaitu semua biaya-biaya yang dikeluarkan oleh bagian dimana besarnya biaya ini tidak dapat dipengaruhi oleh manajer divisi.

7. Common Cost

Common Cost merupakan biaya umum dari perusahaan yang tidak dapat dipisah-pisahkan untuk setiap divisi.

Dengan adanya Segment Performance Report sangat membantu bagi perusahaan khususnya manajer puncak atau direktur utama melihat setiap divisi yang ada. Dengan ini kita dapat melihat keuntungan lebih besar yang dihasilkan oleh divisi tepung kelapa, dibandingkan yang dihasilkan oleh divisi kopra. Sehingga dengan demikian manajer puncak atau direktur utama dapat memberi motivasi lagi kepada divisi kopra untuk meningkatkan keuntungan yang diperoleh. Manajer puncak atau direktur utama juga dapat memberi motivasi lagi kepada kedua divisi untuk terus meningkatkan prestasi yang diperoleh, tanpa membebankan biaya yang tidak dapat dikendalikan (uncontrollable cost) oleh manajer produksi, melainkan mengukur lewat biaya tetap terkendali (controllable cost) oleh manajer produksi yang merupakan tanggung jawab dan wewenangnya.

\section{Kesimpulan}

\section{PENUTUP}

Berdasarkan penelitian yang dilakukan oleh penulis terhadap PT. Janur Kawanua Indonesia dengan menggunakan Segment Performance Report, maka dapat dikemukakan beberapa hal yang dapat disimpulkan sebagai berikut :

1. Perusahaan masih menggunakan laporan yang bersifat konvensional, laporan biaya produksi dan biaya operasional yang dihasilkan ini belum memisahkan antara biaya-biaya yang dapat dikendalikan dan biayabiaya yang tak dapat dikendalikan.

2. Karena belum dipisahkan antara biaya tetap terkendali dan biaya tidak terkendali, maka perusahaan tidak dapat menilai prestasi dengan baik berdasarkan biaya yang dapat dikendalikan oleh masing-masing divisi.

\section{Saran}

Berdasarkan penelitian yang dihasilkan oleh penulis, maka dapat ditarik saran sebagai berikut:

1. Laporan biaya produksi dan biaya operasional yang dihasilkan PT. Janur Kawanua Indonesia sebaiknya dipisahkan antara biaya variabel, biaya yang dapat dikendalikan, serta biaya-biaya yang tidak dapat dikendalikan. Hal ini memudahkan manajer pusat untuk melakukan penilaian prestasi/kinerja manajer masing-masing divisi.

2. Sebaiknya PT. Janur Kawanua Indonesia menetapkan penyusunan laporan pertanggung jawaban untuk setiap divisi atau bagian sesuai dengan konsep Segment Performance Report. Dimana divisi tepung kelapa dan divisi kopra sebagai pusat pertanggung jawab laba. Dengan ini Direktur Utama dapat menilai prestasi masing-masing divisi.

3. Dalam penilaian prestasi/kinerja manajer sebaiknya perusahaan melihat berdasarkan kontribusi divisi atau bagian, dimana masing-masing divisi biaya dibebankan biaya produksi dan biaya operasional yang dapat dikendalikan masing-masing divisi.

\section{DAFTAR PUSTAKA}

Anthony, Robert., Dearden, John. 2003. Sistem Pengendalian Manajemen. Terjemahan Edisi Kesepuluh. Erlangga. Jakarta.

Barbee, Fred. 2013. Princeples Of Accounting. University of Alaska System. Fairbanks Alaska. http:// www.google.com. faculty.cbpp.uaa.alaska.edu. 3 Oktober 2013.

Halim, Abdul., Tjahjono, Achmad., Husein, Fukri. 2009. Sistem Pengendalian Manajemen. Edisi revisi. UPP STIM YKPN. Yogyakarta.

Mulyadi, Arief. 2006. Manajemen Strategik : Perencanaan \& Manajemen Kinerja. Prestasi Pustaka, Jakarta.

Nizar, Nur, M., Syahrul, M. 2000. Kamus Akuntansi. Cetakan Pertama. Citra Harta Prima. Jakarta.

Samryn, L.M. 2012. Akuntansi Manajemen - Informasi Biaya Untuk Mengendalikan Aktivitas Operasi \& Investasi. Kencana. Jakarta. 
Sanger, Yussy. 2005. Penerapan Segment Performance Report Sebagai Alat Penilaian Prestasi Manajer Divisi Pada PT. Astra International Isuzu Manado. Skripsi (tidak dipublikasikan). Universitas Sam Ratulangi. Manado.

Simamora, Henry. 2012. Akuntansi Manajemen. Edisi III. Star Gate Publisher. Riau.

Uli, Megah. 2009. Analisis Penerapan Akuntansi Pertanggung Jawaban Sebagai Alat Penilaian Kinerja Manajer Pusat Pendapatan Pada PT. Astra International cabang Sisingamangaraja. Skripsi (tidak dipublikasikan). Universitas Sam Ratulangi. Manado.

Warindrani, Armila. 2006. Akuntansi Manajemen. Graha Ilmu. Yogyakarta. 